\title{
POMIĘDZY DATA SCIENCE A PERFORMANSEM. O NIEKTÓRYCH WYZWANIACH STOJĄCYCH PRZED WSPÓLCZESNĄ SOCJOLOGIĄ
}

Kto płaci muzykantom, zamawia melodie $e^{*}$.

\section{WPROWADZENIE}

Cele niniejszego tekstu są dwa. Z jednej strony próbuję dokonać rekapitulacji dotyczącej stanu współczesnej socjologii i wyzwań stojących przed naszą dyscypliną. Tego rodzaju cel, mimo że opisowy, jest dość ambitny i musi wiąać się z licznymi uproszczeniami. Nie tylko z powodu niewielkiej objętości tekstu, ale również wskutek złożoności problemu, który mnie interesuje. $\mathrm{Z}$ drugiej strony próbuję wyartykułować prognozę dotyczącą dalszego rozwoju naszej dyscypliny. Wszelkie prognozy mają zawsze charakter warunkowy, nie inaczej jest z moja. Natomiast warto w tym kontekście zauważyć, że prognoza może być trafna albo nietrafna, niezależnie od przyjętych założeń. Innymi słowy, dopuszczam następujące możliwości:

a) diagnoza i prognoza sa trafne;

b) diagnoza jest trafna, ale prognoza nie jest trafna;

c) diagnoza nie jest trafna, ale prognoza jest trafna;

d) zarówno diagnoza, jak i prognoza są nietrafne.

Oczywiście, tekst pisałem, będąc przekonanym o tym, że wszystko wygląda jak w podpunkcie „a”.

Pisanie o wyzwaniach stojących przed współczesną socjologią wymaga przyjęcia rozmaitych założeń. Z jednej strony powinny to być jakieś założenia odnośnie do sytuacji, w której znajduje się socjologia (i w wymiarze teoretycznym, i w praktycznym). Z drugiej - nieuchronne wydaja się pewne założenia normatywne, tj. dotyczące tego, jak nasza dyscyplina powinna wyglądać.

W pierwszej sprawie przyjmuję dość jasno określone stanowisko. Trend, który próbuję opisać, można scharakteryzować następująco: socjologia jako dyscyplina wchodzi w trajektorię bycia perspektywą niszowa. Żeby sprawa była jasna, socjologia jest obecnie uznaną i uprawianą na całym świecie dyscyplina akademicka. Przy tym jest to dyscyplina silnie zinstytucjonalizowana i zakorzeniona na uniwersytetach. Jest to fakt niepodważalny i nie wydaje się,

* Elias (2003): 4. 
żeby w najbliższych latach miało się cokolwiek zmienić. Ale jednocześnie coraz częściej jej dotychczasowe funkcje są przejmowane w świecie poza akademia przez badaczy, którzy owszem analizują procesy społeczne, ale z samą socjologią (tj. z jej tradycja, metodami czy wrażliwościa) czy z innymi naukami społecznymi nie mają nic wspólnego. Nie traktuję tego trendu jako zjawiska, które chciałbym wartościować czy traktować w trybie jakiegoś zagrożenia. Jest to dla mnie interesujący fakt społeczny, który chciałbym poddać namysłowi.

W drugiej sprawie - czyli w kwestii założeń normatywnych - nie mam wyrobionego zdania. Nie wiem, jak powinna wyglądać socjologia. Wiem, że socjologia pełniła i pełni rozmaite funkcje ${ }^{1}$. Dostrzegam zarówno zalety, jak i wady obecnego stanu rzeczy, czyli pluralizmu metodologicznego oraz teoretycznego. I pewnie mógłbym się określić jako krytyczny zwolennik różnorodności - mialbym jednak problem z precyzyjną artykulacją tego stanowiska.

I jeszcze dwie uwagi. Niniejszy tekst ma charakter eseju socjologicznego ${ }^{2}$ ze wszystkimi zaletami i wadami tego podejścia. Natomiast problem, który opisuję, ma - moim zdaniem - charakter globalny, a nie lokalny. Dotyczy zarówno socjologii polskiej, jak i czeskiej, brytyjskiej czy amerykańskiej. Zatem poniżej nie różnicuję mojego opisu kulturowo czy narodowo.

\section{GDZIE JESTEŚMY?}

Dość niekontrowersyjne wydaje się stwierdzenie, że współczesna socjologia jest bardzo silnie zróżnicowana wewnętrznie. Wiąże się z tym drugi, również raczej niekontestowany, fakt, że mamy współcześnie do czynienia z tak dużą produkcją wiedzy naukowej, w tym socjologicznej (w postaci artykułów, monografii, raportów z badań...), iż jest to nie do ogarnięcia z perspektywy pojedynczego badacza. Wyartykułowany kilkanaście lat temu przez Jerzego Szackiego metaforyczny opis stanu naszej dyscypliny wydaje się całkiem realistycznym opisem rzeczywistości: „Socjologia współczesna to istna Wieża Babel. Nikt, w gruncie rzeczy, nie wie dobrze, co się w niej dzieje i jak daleko zajdzie jej różnicowanie. Jeszcze trochę, a nie będziemy w stanie pobieżnie choćby przeglądać wszystkich publikacji z zakresu naszych własnych na pozór specjalizacji”’. Podobne tezy wygłaszało wielu innych badaczy, np. Marek Ziółkowski piszący, że „współczesna socjologia jest [...] coraz wyraźniej dyscypliną wieloparadygmatyczną i jednocześnie pozbawiona jasnych granic"4, czy Andrzej Kojder próbujący opisać sytuację w socjologii za pomocą kategorii postdyscyplinarności ${ }^{5}$. W użyciu są również inne pojęcia; niektóre z nich sa wyraźnie wartościujące, a inne nieco bardziej neutralne. Niemniej u podłoża tych rozmaitych ujęć w większości przypadków leży problem kryzysu socjologii

\footnotetext{
1 Por. Mucha (2017).

2 Pawlak (2015): 324-325.

${ }^{3}$ Szacki (2007): 28.

${ }^{4}$ Ziółkowski (2006): 18.

${ }^{5}$ Kojder (2012).
} 
(kryzysu w socjologii, kryzysu i socjologii, poczucia kryzysu w socjologii...), czyli temat dyskutowany namiętnie od kilkudziesięciu lat, który doczekał się bogatej literatury, zarówno światowej, jak i polskiej6.

Z perspektywy prowadzonej tu argumentacji ważne jest co innego. Jedna z cech charakterystycznych współczesnej socjologii jest nie tylko brak możliwości ogarnięcia konkretnych jej obszarów przez poszczególnych badaczy, ale także brak wspólnej płaszczyzny porozumienia w obrębie dyscypliny. Konsekwencją jest coraz silniejsze zróżnicowanie wewnętrzne i brak pomostów łączących poszczególne nurty socjologii. Rosnące zróżnicowanie ma nie tylko wymiar teoretyczny, ale również metodologiczny. Żeby sprawa była jasna: nie jest to coś, co by dotyczyło wyłącznie socjologii - w jednym z artykułów powstałych w obrębie pedagogiki znalazłem określenie „metodologiczny Hyde Park" , które równie dobrze pasowałoby do socjologii. Podobnie zreszta jak poniższa charakterystyka: „Przyglądając się mapie realizowanych praktyk badawczych, coraz trudniej dostrzec uniwersalne i powszechnie przyjęte zasady, którymi rządzi się współczesna metodologia zorientowana na badanie świata społecznego. Wydaje się, iż najważniejszym priorytetem jest tu dążenie do eksploracji określonej problematyki, realizowane w warunkach autonomii badacza. Zatem coraz częściej spotykamy się z niepewnością nieoczywistością, wątpliwościa, dyskusyjnością kontrowersyjnością i sporem jako istotnymi właściwościami praktyk badawczych"8.

Mamy zatem występujące obok siebie dość odmienne wizje tego, co jest przedmiotem zainteresowania socjologii (poczynając od fundamentalnych kwestii: czy istnieje coś takiego jak społeczeństwo czy też nie?), jak ów przedmiot należy badać, czy wreszcie za pomoca jakich kategorii teoretycznych powinno się opisywać rzeczywistość. Jeszcze raz trzeba podkreślić, że od dawna wskazywało na taki stan rzeczy wielu badaczy funkcjonujących w głównym nurcie socjologii światowej: akceptując go ${ }^{9}$ bądź też podchodząc do niego z wyraźną niechęcią ${ }^{10}$.

Konsekwencją jest sytuacja, którą częściowo można określić słowami Paula Feyerabenda anything goes. Częściowo, ponieważ występujący w obrębie naszej dyscypliny eklektyzm nie znaczy, że wszystko traktowane jest równie poważnie. Sa podejścia uznawane powszechnie za wartościowe i takie, które są zdecydowanie niszowe, sa mody intelektualne, jest ponowne odkrywanie tradycji, jest miejsce zarówno dla fetyszyzmu metodologicznego, jak i anarchizmu epistemologicznego. Co ważne, ten stan rzeczy został właściwie całkowicie znormalizowany i nie jest traktowany jako coś problematycznego - przynajmniej przez większość teoretyków i badaczy.

Nie chciałbym tu rozstrzygać, jakie są przyczyny tego wszystkiego. Możliwych odpowiedzi jest wiele, np. rosnąca złożoność świata, wewnętrzna ewolucja samej dyscypliny, specyficzna organizacja pracy naukowej w obszarze

\footnotetext{
6 Zob. Wielecki (2012): 359-383.

7 Pryszmont-Ciecielska (2016): 156-157.

8 Pryszmont-Ciecielska (2016): 155-156.

9 Zob. Ritzer (2011).

10 Zob. Turner (2013).
} 
nauk społecznych. Można byłoby wymieniać tak dość długo. Ciekawsze były próby podejmowane w celu zmiany tej sytuacji. Mam wrażenie, że w socjologii, zanim przeszła $\mathrm{w}$ fazę rzeczywistego pogodzenia się $\mathrm{z}$ wieloparadygmatycznościa, wewnętrznym zróżnicowaniem i eklektyzmem, dominowało przekonanie, zgodnie z którym nasz dyscyplina powinna zostać ujednolicona przede wszystkim teoretycznie. Inaczej rzecz ujmując, dość długo rozgrywał się konkurs na Izaaca Newtona socjologii. Propozycje Talcotta Parsonsa, Jamesa Colemana, Pierre'a Bourdieu, Anthony'ego Giddensa i wielu innych szły właśnie w tym kierunku. Do tej pory zresztą można znaleźć ślady takiego rozumowania.

W kontekście powyższego należy dodać, że zupełnie odmienna ścieżką rozwoju jest ta, którą poszli w ostatnich dekadach psychologowie. Dyscyplina ta bardzo wyraźnie zorientowała się na maksymalne zbliżenie się do standardów przyrodoznawstwa, przede wszystkim przez stworzenie spójnych standardów metodologicznych. W praktyce oznacza to obecnie dominację ilościowej metody eksperymentalnej, wykorzystanie zaawansowanych analiz statystycznych oraz dążenie do kumulacji wiedzy w postaci metaanaliz. Abstrahując od zalet i wad takiej strategii, można byłoby analogicznie założyć, że socjologię również ujednolici ten, kto będzie w stanie narzucić wspólną metodologię, a nie ten, kto przekona większość do swojej teorii. Warto podkreślić, że w tym kierunku - czyli obietnicy metodologicznej - szli w ostatnich dekadach m.in. przedstawiciele teorii aktora-sieci (actor-network theory) ${ }^{11}$ czy analizy sieci społecznych (social network analysis $)^{12}$. Trudno jednak mówić o sukcesie, tj. narzuceniu standardów metodologicznych dyscyplinie, w którymkolwiek z powyższych przypadków. Szczególnie w przypadku teorii aktora-sieci obietnica metodologiczna okazała się nieudana ${ }^{13}$.

Osobną tendencją którą również można zaklasyfikować jako próbę poradzenia sobie z wieloparadygmatycznością i eklektyzmem, były wszelkiego rodzaju próby przekierowania istoty socjologii poza pole nauki. W praktyce było to związane $\mathrm{z}$ metodologia jakościową i przekierowywaniem badań w stronę sztuki (np. traktowanie aktów performansu jako praktyki badawczej ${ }^{14}$ ) albo ze świadomym upolitycznianiem socjologii (np. projekt socjologii publicznej Michaela Burawoya z pierwszej dekady XXI w. ${ }^{15}$ ). Z dzisiejszej perspektywy można powiedzieć, że próby te jedynie zwiększyły problemy związane ze statusem i tożsamością dyscypliny.

\section{PERSPEKTYWA DATA SCIENCE}

Czas na ostatni klocek mojej układanki, ale zacząc chciałbym od cytatu, pokazującego, że socjologia nadal może pełnić istotne funkcje poznawcze i praktyczne: „W Internecie powstały komory pogłosowe pełne nieprawdziwych in-

\footnotetext{
11 Zob. Latour (2010).

12 Zob. Wasserman, Faust (1994); Degenne, Forse (1999).

13 Por. Sojak, Afeltowicz, Pietrowicz (2019).

${ }^{14}$ Finley (2009); por. Pryszmont-Ciesielska (2016).

15 Burawoy (2009).
} 
formacji. Rozprzestrzenianie się kłamstw teorii spiskowych i bezpodstawnych pogłosek ma charakter epidemii i na początku XXI w. stanowi jeden z najbardziej niepokojących trendów społecznych. Socjologowie badaja te komory, analizujac metodami obliczeniowymi ślady pozostawiane przez ludzi na Facebooku, Twitterze i w innych mediach społecznościowych"16. Brzmi zachęcająco, więc idźmy dalej: „Socjologowie dokonali w ostatnich latach wyraźnego postępu w wyjaśnianiu procesów rozprzestrzeniania i wykorzystania informacji, ich wpływu na formowanie się opinii i stosunków międzyludzkich" ${ }^{17}$. Kim są owi socjologowie, tworzacy front badawczy w nowej subdyscyplinie, chciałoby się zapytać. Oto i oni: „Nasz zespół tworzą dwaj fizycy (Guido Caidarelli i Antonio Scala), statystyk (Alessandro Bessi, obecnie w Information Sciences Institute, University of Southern California), matematyczka (Michela Del Vicario) oraz dwoje informatyków (Fabiana Zollo i ja)"18. Wszystkie powyższe cytaty pochodzą z artykułu Waltera Quattrociocchiego Wirtualne komory pogłosowe z periodyku „Świat Nauki” nr 6/2017. Przykład jest oczywiście anegdotyczny, ale pokazuje pewne zjawisko, które wydaje mi się ważne.

Tym zjawiskiem jest pojawienie się już kilkanaście lat temu podejścia, które w systematyczny, ilościowy sposób zajmuje się analizą gromadzonych cyfrowo nieustrukturyzowanych danych dotyczących zachowań ludzi między innymi po to, by wyciagać wnioski dotyczące rozmaitych zbiorowości. Przy tym tego rodzaju analizy - choć czasami są określane jako socjologiczne (jak w powyższym cytacie) - nie korzystaja z dorobku socjologii, ani w odniesieniu do tradycji teoretycznej, ani w odniesieniu do metod badawczych. Najłatwiej podejście to określić zbiorczą nazwą data science, ale w rzeczywistości w obiegu funkcjonowało i funkcjonuje nadal wiele innych szyldów, obejmujących przynajmniej częściowo tego rodzaju praktyki, m.in. big data, nauki o złożoności, network science czy fizyka społeczna. W swoich publikacjach, zajmując się po części tym zagadnieniem, używałem metaforycznego określenia „przyczółki”"

Pojawienie się tego podejścia, czy raczej: możliwość zastapienia empirycznej ilościowej socjologii przez jakąś odmianę data science, jest problemem dyskutowanym w obrębie samej socjologii od kilkunastu lat. Artykuł Mike'a Savage'a i Rogera Burrowsa z 2007 r. The coming crisis of empirical sociology $y^{20}$ stał się jednym z najczęściej cytowanych tekstów socjologicznych ostatniej dekady. Swoją argumentację Savage i Burrows rozwijali w kolejnych publikacjach ${ }^{21}$, również dość szeroko dyskutowanych. Główna idea wyżej wymienionych autorów zasadzała się na przekonaniu, że socjologowie nie są przygotowani na wyzwania, które niesie ze sobą analiza masowo gromadzonych we współczesnym społeczeństwie danych, np. transakcyjnych (dziś powiedzielibyśmy: okruchów cyfrowych), które sa rutynowo przetwarzane i analizowane przez rozmaite instytucje prywatne i publiczne. Dyskusja zapoczątkowana w 2007 r. trwa do tej

\footnotetext{
16 Quattrociocchi (2017): 42.

17 Quattrociocchi (2017): 44.

18 Quattrociocchi (2017).

19 Afeltowicz, Pietrowicz (2013); Pietrowicz (2016).

20 Savage, Burrows (2007).

21 Por. Savage, Burrows (2009); Burrows, Savage (2014).
} 
pory, również wśród badaczy ilościowych. Z publikacji, który pojawiły się relatywnie niedawno, warto wymienić specjalny numer periodyku „Public Opinion Quaterly” z 2017 r., zatytułowany Survey Research, Today and Tomorrow, do którego Peter V. Miller napisał wprowadzenie: Is there a future for surveys ${ }^{22}$ Problematyka ta się pojawia się również w odniesieniu do potencjału, który dla socjologów może nieść analiza big data. Idea obliczeniowych nauk społecznych (computional social science) pojawiła się ponad dziesięć lat temu ${ }^{23}$ i regularnie powraca, również w dość nieoczywistych artykulacjach ${ }^{24}$.

Pytanie, które należy w tym momencie zadać, brzmi następująco: Czy z perspektywy roku 2020 można powiedzieć, że data science zmieniła socjologię (czy szerzej: nauki społeczne)? Czy wyparła socjologię z jakiegoś obszaru w obrębie pola akademickiego? Albo może jej dorobek stał się istotnym rzeczywistym wyzwaniem dla naszej dyscypliny czy innych nauk społecznych? Czy wreszcie obliczeniowe nauki społeczne stały się ważnym segmentem badań akademickich? Odpowiedź na te wszystkie pytania brzmi: nie. Oczywiście w rozmaitych periodykach naukowych ukazuja się artykuły, często bardzo interesujące i inspirujące, pisane przez zespoły badawcze, takie jak wymieniony wcześniej zespół Quattrociocchiego, ale w porównaniu z pracami socjologów na te same tematy jest to pewien margines. Czy w związu z tym obawy Savage’a i Burrowsa okazały się płonne? Również nie można tego powiedzieć. Otóż skądinąd wiadomo, że data science rozwija się bardzo gwałtownie. Tylko, że o tym rozwoju zasadniczo nie przeczytamy w periodykach naukowych, ale dowiadujemy się o nim np. przy okazji afery Cambridge Analytica ${ }^{25}$, gdzie wykorzystanie danych z sieci społecznościowych miało przyczynić się do zwycięstwa Donalda Trumpa w wyborach prezydenckich w USA, przy okazji ujawnienia przez Edwarda Snowdena funkcjonowania systemu PRISM ${ }^{26}$, opierającego się na masowym zbieraniu danych ze światowych sieci telekomunikacyjnych i analizowaniu ich na różne sposoby przez amerykańskie służby specjalne, kiedy okazuje się, że najdokładniejsze szacunki dotyczące liczby Ukraińców w Polsce i ich planów życiowych nie pochodza od badaczy akademickich czy z GUS-u, ale zostały zebrane za pomoca aplikacji ze smartfonów przez firmę Selectivvv ${ }^{27}$, czy wreszcie w kontekście debat dotyczących zbierania danych przez smartfony w USA ${ }^{28}$. To wszystko są okruchy rewolucyjnych zmian, które dokonuja się od kilkunastu lat przede wszystkim poza akademia (ale - jak wspomniałem - z wypustkami w nauce): w sferze biznesowej (wielkie korporacje informatyczne, brokerzy danych itp.) i w aparacie państwowym (tutaj przodują służby specjalne).

Dlaczego ten gwałtowny rozwój nastapił poza akademią? Relatywnie szybko okazało się bowiem, że data science to nie tylko podejście o dużym potencja-

\footnotetext{
${ }^{22}$ Miller (2017).

23 Lazer et al. (2009).

24 Por. Jemielniak (2018).

25 Schneble, Simone, Shaw (2018).

26 Snowden (2019); Edgar (2017).

27 Selectivv (2019).

28 Thompson, Warzel (2019).
} 
le analityczno-opisowym, ale też dobry punkt wyjścia do inżynierii społecznej. O ile o dwóch głośnych eksperymentach Facebooka w zakresie wywierania wpływu można było przeczytać jeszcze w periodykach naukowych ${ }^{29}$, to od tego czasu wiedza tego rodzaju zaczęła być traktowana jako cenna rynkowo, a z drugiej strony badania tego dotyczące oceniono jako nieetyczne i przestały być publikowane.

Tymczasem trend technologiczny jest jednoznaczny. Na całym świecie mamy do czynienia z coraz większym nasyceniem urządzeniami cyfrowymi. Wszystkie urządzenia tego rodzaju zajmują się zbieraniem danych o swoich użytkownikach. Wdrażanie sieci 5G i związany z tym rozwój Internetu rzeczy sprawiaja, że danych będzie coraz więcej. Doskonalenie systemów sztucznej inteligencji powoduje z kolei ulepszenie narzędzi analitycznych. Metaforycznie rzecz ujmując, właśnie budowane są autostrady, po których będą jeździć przedstawiciele data science, a właściwie już jeżdżą.

Chciałbym się posłużyć pewną analogią. Początek nowoczesnej socjologii empirycznej to w dużej mierze efekt badań nad armią amerykańską na zlecenie rządowe, prowadzonych poza akademią w trakcie drugiej wojny światowej, czego efektem były m.in. monografie zbiorczo określane tytułem The American Soldier. Jak zauważył Antoni Sułek: ,wydane w latach 1949-1950 cztery tomy Studies in Social Psychology in World War II są dziśs powszechnie uważane nie tylko za fundamentalne badania socjologii wojska, ale i za jedne z założycielskich badań i dzieł socjologii empirycznej, odegrały one ważną rolę w rozwoju i instytucjonalizacji empirycznych badań społecznych [...]. Dla socjologii ilościowej Żotnierz amerykański jest tym, czym dla socjologii jakościowej Chłop polski, w Europie i Ameryce" 30 . Badania te prowadzili socjologowie, którzy mogli w ten sposób doskonalić swoje narzędzia. W tym czasie tego rodzaju wykorzystywanie badaczy społecznych było czymś powszechnym: prominentni antropolodzy amerykańscy dość powszechnie pracowali dla służb specjalnych w trakcie drugiej wojny światowej i po jej zakończeniu ${ }^{31}$. Jeszcze w latach sześćdziesiątych do projektu Camelot, który z powodów etycznych nie został w końcu uruchomiony, potrzebni byli przedstawiciele różnych dyscyplin (socjologowie, ekonomiści, antropolodzy czy politolodzy) ${ }^{32}$. Obecnie sytuacja jest zupełnie inna. Po części dzięki rozwojowi data science zmienia się gospodarka oraz polityka (a przynajmniej część polityki) najbardziej rozwiniętych państw świata. Do opisu rzeczywistości społecznej i prowadzenia skutecznych działań podmioty rynkowe i polityczne nie potrzebuja już jednak socjologów (nie tylko akademickich, ale szerzej: badaczy wykształconych socjologicznie).

Wobec powyższego rozumowania można przytoczyć wiele argumentów krytycznych. Do kilku najczęściej przeze mnie spotykanych chciałbym odnieść się od razu. Można zatem wskazywać, że opisana powyżej sytuacja nie jest niczym nowym. Już wcześniej mieliśmy do czynienia z próbami wejścia w pole nauk

\footnotetext{
29 Bond et al. (2012); Kramer, Guillory, Hancock (2014).

30 Sułek (2017): 60.

31 Kowalski (2012): 123-124.

32 Solovoy (2001).
} 
społecznych (w tym socjologii) przez przedstawicieli rozmaitych innych dyscyplin. Najbardziej znanymi przykładami tego rodzaju mogą być powstała w połowie XX w. cybernetyka oraz rozwinięta w latach siedemdziesiątych XX w. socjobiologia (w tej części, w której zajmowała się ludźmi). Z dzisiejszej perspektywy obydwie te dyscypliny i ich roszczenia mogą wydawać się zabawne, ale nie było tak w momencie, kiedy powstawały. Zarówno cybernetyka, jak i socjobiologia wydawały się bardzo ekspansywne, dawały przy tym obietnicę syntezy i „unaukowienia” socjologii. Tak się jednak nie stało, a dyscypliny te nie zostały trwale akademicko zinstytucjonalizowane w obszarze nauk społecznych. Cybernetyka dość szybko przestała istnieć jako odrębna dyscyplina, a socjobiologia (czy raczej część jej ustaleń) stała się istotnym punktem odniesienia psychologii ewolucyjnej, czyli subdyscypliny zdecydowanie bardziej niszowej. Istnieje jednak dość istotna różnica między tymi (i innymi podobnymi) przypadkami a data science. Cybernetyka czy socjobiologia były próbami stworzenia alternatywy względem nauk społecznych w obrębie pola nauki (w świecie akademii). W opisywanym powyżej przypadku tak nie jest. Data science rozumiana jako podejście zajmujące się ludźmi i ich zachowaniami instytucjonalizuje się (i to dość skutecznie) przede wszystkim poza światem akademii (ale zachowując $\mathrm{w}$ akademii przyczółki funkcjonujące raczej poza naukami społecznymi). Z tego samego powodu jest pewna różnica pomiędzy complexity science ${ }^{33}$ (przedsięwzięciem przede wszystkim akademickim) a data science (przedsięwzięciem przede wszystkim pozaakademickim). Moim zdaniem jest to różnica fundamentalna, ponieważ to właśnie na owej instytucjonalizacji pozaakademickiej opiera się moja prognoza. W przypadku pozostawania w obrębie pola akademickiego mieliśmy do czynienia ze standardową debata naukową (co nie znaczy oczywiście, że opartą wyłącznie na argumentach merytorycznych). Obecnie z tego rodzaju debatą nie mamy do czynienia (a jeśli już, to jednostronna, tzn. wyłącznie w obrębie socjologii - przykładami moga być przywołane wcześniej artykuły Burrowsa i Savage'a oraz reakcje na nie).

Kolejnym argumentem jest przekonanie, że o ile badania ilościowe być może rzeczywiście przestana być domeną socjologów, to badacze społeczni będą niezbędni do realizacji badań jakościowych, rozumiejących, pogłębiających perspektywę rozmaitych podmiotów zamawiających analizy. W chwili obecnej jest to niewątpliwie stanowisko dające się uzasadnić: rzeczywiście istnieje popyt podmiotów rynkowych i politycznych na badania jakościowe, realizowane metodami standardowymi (podobnie zresztą nadal jest w przypadku standardowych socjologicznych badań ilościowych). Nie musi być to jednak stan trwały. W miarę zwiększenia opomiarowania (liczby urządzeń zbierajacych danych o zachowaniach ludzi) i zwiększania znaczenia brokerów danych można sobie bezproblemowo wyobrazić, że funkcje badań jakościowych również zostaną przejęte przez przedstawicieli data science.

Innym argumentem, z którym zetknąłem się podczas rozmaitych dyskusji, jest próba pokazania, że badacze z kręgu data science są (a przynajmniej by-

${ }^{33} \mathrm{O}$ wyzwaniach socjologii w kontekście rozwoju nauki o złożoności - zob. Drozdowski, Szlendak (2013). 
waja) w wielu aspektach bardzo mało wyrafinowani. Ich obrazy rzeczywistości społecznej sa proste, niezbyt zniuansowane, a w niektórych aspektach zbyt radykalnie upraszczają rzeczywistość. W wielu przypadkach nie sposób się z tym nie zgodzić, tylko że nijak się to ma do przedstawionego tu rozumowania. Przewagą data science jest co innego: możliwość analizy dużej ilości danych w czasie rzeczywistym, dostęp do wiedzy o rzeczywistych zachowaniach bardzo specyficznych grup, rzetelność rozumiana jako powtarzalność i standaryzacja, potencjał modelowania z wykorzystaniem metod uczenia maszynowego... Innymi słowy, to, że w ramach tego podejścia pojawiają się obecnie dość duże uproszczenia, nie ma istotnego znaczenia. Oferta obejmuje coś, czego socjologia nie jest w stanie dać. Inne nauki społeczne również.

\section{PODSUMOWANIE}

Jeśli zarysowany powyżej stan rzeczy oraz związana z nia prognoza sa trafne, to socjologia stoi obecnie przed dwoma wyzwaniami. A właściwie, precyzyjniej rzecz ujmując, to nie socjologia stoi przed tymi wyzwaniami, ale socjologowie. Sa to wyzwania istotne dla praktyki, metodologii i teorii: jedno z nich ma charakter wewnętrzny, a drugie zewnętrzny.

Wyzwanie wewnętrzne można określić (używając przywołanej już metafory Szackiego) jako próbę uporządkowania wieży Babel. W jaki sposób zachować względną spójność dyscypliny, utrzymać wewnętrzną komunikację i dać możliwość choćby częściowej kumulacji wiedzy w sytuacji radykalnego zróżnicowania teoretycznego i metodologicznego?

Wyzwanie wewnętrzne nie byłoby - moim zdaniem - czymś szczególnie palącym, gdyby nie wyzwanie zewnętrzne. Jaki powinien być stosunek socjologów do data science? Ignorowanie? Krytyczny namysł? Selektywne wykorzystanie? Próba syntezy?

I właśnie te dwa wyzwania stanowią punkt wyjścia możliwości, które rysuja się przed socjologią. Jakie są owe możliwości? (1) Nic nie zmieniać; (2) wyostrzyć funkcję krytyczną i jeszcze bardziej się upolitycznić, czy to pod sztandarami socjologii publicznej, czy w jakiś inny sposób; (3) postawić przede wszystkim na badania jakościowe, ewoluując zdecydowanie w stronę humanistyki, sztuki, performansu; (4) pójść w ślady psychologii, stawiając przede wszystkim na zestandaryzowaną metodologię ilościowa; i wreszcie (5) spróbować dokonać syntezy z data science, czyli wymyślić się na nowo. Zdaję sobie sprawę, że poza przypadkiem 1, są to stanowiska na tyle specyficzne, że trudno je uznać za możliwe do realizacji w krótkim przedziale czasowym. To znaczy trudno sobie wyobrazić, żeby większość socjologów wybrała nagle wyłącznie jeden z tych kierunków. To, z czym będziemy mieli do czynienia, czy raczej - to, z czym mamy do czynienia, to sytuacja, w której poszczególne środowiska i badacze, jeśli nie pozostają przy opcji 1, zaczynają podążać w kierunkach opcji 2-4.

Trzy pierwsze opcje oznaczaja powolną zmianę statusu socjologii i w konsekwencji jej marginalizację, szczególnie poza akademią. Moim zdaniem to 
jest scenariusz najbardziej prawdopodobny w kontekście zarysowanego wcześniej wyzwania zewnętrznego. Opcję $4 \mathrm{w}$ dłuższej perspektywie widzę bardzo podobnie. Opcja 5 jest z kolei trudna do wyobrażenia w przypadku dyscypliny silnie zinstytucjonalizowanej. Wymagałaby odrzucenia znacznej części tradycji socjologicznej i de facto wymyślenia się na nowo. Wymagałaby również zmiany programów kształcenia studentów socjologii i - z drugiej strony przyswojenia przez badaczy zupełnie nowej wiedzy. Nie wydaje się to realne. Retorycznie można na przykład zapytać, ilu socjologów stosuje obecnie metody uczenia maszynowego.

Spójrzmy na to w następujący sposób - oto mamy współczesną socjologię: tutaj Guillermina Jasso, tam Randal Collins, obok Michael Burawoy, gdzieś z boku Bruno Latour, w jednym miejscu badacze ilościowi, w innym jakościowi... Wszyscy oni przypominają archeologów, którzy przebywając na stanowisku badawczym, małymi szpachelkami odsłaniaja okruchy, miotełkami otrząsają je z pyłu i próbują połączyć w całość. Tymczasem w tle podjechały buldożery przedstawicieli data science i zaczyna się powolne niwelowanie terenu.

Krzysztof Pietrowicz

Uniwersytet Mikotaja Kopernika w Toruniu

krzysztof.pietrowicz@umk.pl

https://orcid.org/0000-0002-0596-4672

Afeltowicz, Ł., Pietrowicz, K. (2013). Maszyny społeczne. Wszystko ujdzie, o ile działa. Warszawa.

Bond, R.M., Fariss, C.J., Jones, J.J., Kramer, A.D.I., Marlow, C., Settle, J.E., Flower, J.H. (2012). A61-million-person experiment in social influence and political mobilization. Nature 489: $295-298$.

Burawoy, M. (2009). O socjologię publiczną. Przemówienie prezydenckie z roku 2004, [w:] A. Manterys, J. Mucha (red.), Nowe perspektywy teorii socjologicznej. Wybór tekstów. Tłum A. Dziuban. Kraków: 525-561.

Burrows, R., Savage, M. (2014). After the crisis? Big Data and the methodological challenges of empirical sociology. Big Data \& Society April-June: 1-6.

Degenne, A., Forse, M. (1999). Introducing Social Networks. Tłum. A. Borges. London.

Drozdowski, R., Szlendak, T. (2013). Socjologia wobec złożoności współczesnego świata. Studia Socjologiczne 4(211): 7-17.

Edgar, T.H. (2017). Beyond Snowden. Privacy, Mass Surveillance, and the Struggle to Reform the NSA. Washington D.C.

Elias, N. (2003). Zaangażowanie i neutralność. Tłum. J. Stawiński. Warszawa.

Finley, S. (2009). Badania posługujące się sztuka. Rewolucyjna pedagogika oparta na performansie, [w:] N.K. Denzin, Y.S Lincoln (red.), Metody badań jakościowych. Tom 2. Tłum. M. Podgórski. Warszawa: 57-79.

Jemielniak, D. (2018). Socjologia 2.0: o potrzebie łączenia Big Data z etnografią cyfrowa, wyzwaniach jakościowej socjologii cyfrowej i systematyzacji pojęć. Studia Socjologiczne 2(229): $7-29$.

Kojder, A. (2012). Postdyscyplinarność socjologii, [w:] J. Zamecka (red.), Normy, dewiacje i kontrola społeczna. Tom 13. Warszawa: 15-35.

Kowalski, M. (2012). Antropologia na wojnie. Historia i teraźniejszość udziału antropologów w konfliktach wojennych. Zeszyty Naukowe WSOWL 1(163): 119-132.

Kramer, A., Guillory, J., Hancock, J. (2014). Experimental evidence of massive-scale emotional contagion through social networks. Proceedings of the National Academy of Sciences 111(24): 8788-8790. 
Latour, B. (2010). Splatając na nowo to, co społeczne: wprowadzenie do teorii aktora-sieci. Tłum. A. Derra, K. Abriszewski. Kraków.

Lazer, D., Pentland, A., Adamic, L., Aral, S., Barabási, A-L., Brever, D., Chirstiakis, N., Condractor, N., Fowler, J., Gutmann, M., Jebara, T., King, G., Macy, M., Roy, D., Van Alstyne, M. (2009). Computational Social Science. Science 323: 721-723.

Miller, P.V. (2017) Is there a future for surveys? Public Opinion Quarterly 81(S1): 205-212.

Mucha, J. (2017). Rola socjologii i socjologów we współczesnym społeczeństwie. Studia Socjologiczne 1(224): 331-338.

Pawlak, M. (2015). Ograniczenia rozwoju socjologii krytycznej. Próba alternatywnego wyjaśnienia. Stan Rzeczy 8(1): 307-326.

Pietrowicz, K. (2016). Podejścia sieciowe w socjologii. Przyczółki, splecenia i przeobrażenia dyscypliny. Bydgoszcz.

Pietrowicz, K. (2019). Dlaczego klasycy? Krótkie rozważania na marginesie lektury C. Wrighta Millsa, [w:] Ł. Krzyżowski, K. Leszczyńska, M. Szmeja (red.), Wyobrażone, przeżyte i przedstawione. Księga jubileuszowa dla Profesora Janusza Muchy. Kraków: 80-93.

Pryszmont-Ciesielska, M. (2016). Metodologiczny Hyde Park i kryzys badacza. Kulisy badań inspirowanych sztuka i performansem. Człowiek - Teraźniejszość - Edukacja 19(3): 155-165.

Quattrociocchi, W. (2017). Wirtualne komory pogłosowe. Świat Nauki - Scientific American 6: $42-45$.

Ritzer, G. (2011). Sociological Theory. Eighth edition. New York.

Savage, M., Burrows, R. (2007) The coming crisis of empirical sociology. Sociology 41(5): 885-899.

Savage, M., Burrows, R. (2009). Some further reflections on the coming crisis of empirical sociology. Sociology 43(4): 765-775.

Schneble, C.O., Simone, B., Shaw, E. (2018). The Cambridge Analytica affair and Internet-mediated research. EMBO Report 19(8):e46579. doi:10.15252/embr.201846579

Selectivv (2019). Czy Ukraińcy wiążą swoją przyszłość z naszym krajem? - najnowsze badanie Selectivv, 07.03.2019. <https://selectivv.com/czy-ukraincy-wiaza-swoja-przyszlosc-z-naszym-krajem-najnowsze-badanie-selectivv>.

Snowden, E. (2019). Pamięć nieulotna. Tłum. M. Jóźwiak, M. Strąkow, B. Jóźwiak. Kraków.

Sojak, R., Afeltowicz, Ł., Pietrowicz, K. (2019). Let it fly high! On the need for ANT with a positivistic inclination. Polish Sociological Review 3(207): 255-269.

Solovoy, M. (2001). Project Camelot and the 1960s epistemological revolution. Rethinking the politics-patronage-social science nexus. Social Studies of Science 31(2): 171-206.

Sułek. A. (2017). Polski szlak The American Soldier. Przyczynek do historii wędrówek idei socjologicznych. Studia Socjologiczne 1(224): 59-79.

Szacki, J. (2007). Socjologia jako Wieża Babel. Studia Socjologiczne 1(184): 27-32.

Thompson, S.A., Warzel, C. (2019). Twelve million phones, one dataset, zero privacy. The New York Times, 19.12.2019. < https://www.nytimes.com/interactive/2019/12/19/opinion/locationtracking-cell-phone.html>.

Turner, J.H. (2013). Contemporary Sociological Theory. Thousand Oaks - London.

Wasserman, S., Faust, K. (eds.) (1994). Social Network Analysis: Methods and Applications. Cambridge - New York.

Wielecki, K. (2012). Kryzys i socjologia. Warszawa.

Ziółkowski, M. (2006). Teoria socjologiczna początku XXI wieku, [w:] A. Jasińska-Kania, L. Nijakowski, J. Szacki, M. Ziółkowski (red.), Współczesne teorie socjologiczne. Tom 1. Warszawa: $15-32$.

\title{
BETWEEN DATA SCIENCE AND PERFORMANCE: ON SOME OF THE CHALLENGES FACING CONTEMPORARY SOCIOLOGY
}

\author{
Sum mary
}

The article is an attempt to describe the state of contemporary sociology and one of the challenges facing our discipline. This challenge is the emergence of data science: an approach that deals in a systematic, quantitative way with the analysis of digitally accumulated unstructured data on 
human behavior. Importantly, data science analyses do not draw on the achievements of sociology, neither in theories nor in the research methods. However, data science is replacing sociology (and other social sciences) outside the academic world. The paper tries to show how data science differs from other, earlier challenges for sociology.

Keywords: data science; computational social science; the crisis of sociology 